\title{
Ocena wiedzy studentów farmacji w zakresie profilaktyki chorób układu krążenia. Część 1. Wiedza w zakresie prewencji pierwotnej
}

\section{Knowledge of pharmacy students regarding the prevention of cardiovascular diseases. Part 1. Knowledge in the field of primary prevention}

\author{
Beata Sarecka-Hujar ${ }^{\bowtie}$, Aneta Ostróżka-Cieślik, Andrzej Jankowski \\ Śląski Uniwersytet Medyczny w Katowicach, Katedra i Zakład Technologii Postaci Leku, ul. Kasztanowa 3, 41-200 Sosnowiec \\ Medical University of Silesia in Katowice, Department of Pharmaceutical Technology \\ $\triangle$ beatasarecka@poczta.onet.pl
}

\begin{abstract}
Introduction: The promotion of a healthy lifestyle, including a healthy diet, smoking cessation and regular exercise are among the primary prevention factors of cardiovascular diseases (CVDs), which are the leading cause of high mortality, especially among men. CVDs are chronic, multifactorial diseases caused by the combination of environmental and genetic risk factors

The aim of the study was to assess the knowledge of pharmacy students from the Medical University of Silesia in Katowice regarding the risk factors of CVDs as well as the health-promoting behaviours of the students.

Materials and methods: A questionnaire-based survey was used for 156 pharmacy students from the Medical University of Silesia in Katowice (123 females and 33 males, mean age $23.4 \pm 1.5$ years). Participation in the survey was voluntary and anonymous. Statistical analysis was performed using Statistica 12.0 (StatSoft).
\end{abstract}

Results: The most important risk factors for CVDs identified by the surveyed students were: overweight/obesity (indicated by $90 \%$ of respondents), hypertension ( $87 \%)$, stress (75\%), and low physical activity (70\%). Almost all the respondents (99\%) knew the principles of a healthy diet, but only $38 \%$ follow them. Only $15 \%$ of respondents smoked cigarettes $(27 \%$ of men vs $11 \%$ of women, $p=0.03$ ). In turn, $57 \%$ of the students admitted that their level of physical activity was moderate, and $5 \%$ did not exercise at all. Alcohol consumption was declared by $66 \%$ of respondents, with no difference in the subgroups of women and men. Conclusions: Cigarette smoking is the most frequent risk factor for CVDs according to the surveyed students. Every third respondent did not follow the principles of a healthy diet and showed low or lack of physical activity. Ongoing education in the primary prevention of CVDs should therefore concern everyone, including those who are or will be professionally involved in medicine. Keywords: cardiovascular disease; primary prevention; risk factors; smoking; body mass index.

\begin{abstract}
ABSTRAKT
Wstęp: Do profilaktyki pierwotnej chorób układu krążenia należy promowanie zdrowego trybu życia, przez m.in. stosowanie zdrowej diety, zaprzestanie palenia czy regularne ćwiczenia fizyczne. Choroby układu krążenia (ChUK) są główną przyczyną wysokiej umieralności, przede wszystkim mężczyzn. Są to przewlekłe, wieloczynnikowe choroby, których etiopatogeneza wynika z oddziaływań między czynnikami środowiskowymi a genetycznymi.

Celem pracy była ocena wiedzy studentów farmacji Śląskiego Uniwersytetu Medycznego w Katowicach (SUM) na temat czynników ryzyka ChUK.

Materiały i metody: Do badań metodą sondażu diagnostycznego wykorzystano autorski kwestionariusz ankiety, który wypełniło 156 studentów farmacji SUM (123 kobiety i 33 mężczyzn; średni wiek 23,4 $\pm 1,5$ lata). Udział w ankiecie był dobrowolny i anonimowy. Analizę statystyczną przeprowadzono z wykorzystaniem programu Statistica 12,0 (StatSoft Inc.).
\end{abstract}

Wyniki: Do najważniejszych czynników ryzyka ChUK wskazanych przez ankietowanych studentów należą: nadwaga/otyłość (90\% osób), nadciśnienie tętnicze ( $87 \%$ ), stres $(75 \%)$ oraz mała aktywność fizyczna (70\%). Prawie wszyscy ankietowani (99\%) znają zasady zdrowego żywienia, jednak tylko 38\% je stosuje. Jedynie $15 \%$ respondentów pali papierosy ( $27 \%$ mężczyzn vs $11 \%$ kobiet, $\mathrm{p}=0$,03). Z kolei $57 \%$ studentów przyznało, że poziom ich aktywności fizycznej jest średni, natomiast $5 \%$ z nich nie ćwiczy wcale. Spożywanie alkoholu zadeklarowało $66 \%$ ankietowanych, przy czym nie wykazano różnic w podgrupach kobiet i mężczyzn. Wnioski: Najczęściej występującym czynnikiem ryzyka ChUK $\mathrm{w}$ ankietowanej grupie studentów jest palenie papierosów. Co trzeci ankietowany nie stosuje zasad zdrowego żywienia i wykazuje niski poziom aktywności fizycznej lub całkowity jej brak. Wydaje się, że ciągłe kształcenie w zakresie profilaktyki pierwotnej ChUK powinno dotyczyć każdego, również osób, które są lub będą związane zawodowo z medycyną.

Słowa kluczowe: choroby układu krążenia; prewencja pierwotna; czynniki ryzyka; palenie papierosów; wskaźnik masy ciała. 


\section{WSTĘP}

Choroby układu krążenia (ChUK), w tym miażdżyca naczyń wieńcowych i będąca jej konsekwencją choroba niedokrwienna serca (ChNS), są główną przyczyną wysokiej umieralności, przede wszystkim mężczyzn. Rzadsze występowanie ChNS u kobiet, zwłaszcza w okresie przedmenopauzalnym, wynika prawdopodobnie z ochronnej roli żeńskich hormonów płciowych [1]. Choroby układu krążenia są przewlekłe oraz wieloczynnikowe, a ich etiopatogeneza wynika z oddziaływań między czynnikami środowiskowymi a genetycznymi.

Jednym z najsilniejszych czynników ryzyka ChNS jest palenie papierosów. U osoby palącej ryzyko wystąpienia ChNS i ostrych incydentów sercowo-naczyniowych, jak zawał serca czy nagła śmierć, wzrasta kilkukrotnie w porównaniu z osobami niepalącymi. Nikotyna stymuluje wydzielanie katecholamin (głównie noradrenaliny, która podwyższa tętno), wpływa niekorzystnie na profil lipidowy, powoduje wzrost ciśnienia tętniczego, nasila trombogenezę i agregację płytek krwi, a także obniża wytwarzanie i uwalnianie prostacykliny przez komórki śródbłonka, co sprzyja zakrzepom i skurczom naczyń. Palenie tytoniu związane jest z podwyższonym stężeniem białek ostrej fazy, głównie białka C-reaktywnego (CRP) i fibrynogenu [2]. U osób z zaawansowanymi zmianami miażdżycowymi palenie sprzyja destabilizacji blaszki miażdżycowej, jej pękaniu i powstawaniu zakrzepu [3]. Silnym czynnikiem ryzyka rozwoju ChNS jest również otyłość [4]. Udokumentowane są związki między otyłością a opornością na insulinę, stanem zapalnym, cukrzycą typu II, dyslipidemią, zakrzepicą, nadciśnieniem oraz miażdżycą i udarem niedokrwiennym mózgu. Nawet niewielki wzrost wskaźnika masy ciała (body mass index - BMI) jest związany z ryzykiem zawału mięśnia sercowego [5]. Otyłość i nadwaga w dorosłym życiu powodują wzrost ryzyka przedwczesnej śmierci [6].

Kolejnym uznanym czynnikiem ryzyka miażdżycy jest nadciśnienie tętnicze. U chorych z nadciśnieniem obserwowana jest zwiększona synteza anionorodnika ponadtlenkowego, a także podwyższone stężenie angiotensyny II, która wykazuje działanie wazokonstrykcyjne i może stymulować procesy zapalne w ścianie naczyniowej. Z rozwojem zmian miażdżycowych i chorób sercowo-naczyniowych koreluje także wysoki poziom cholesterolu frakcji LDL (low density lipoprotein) [7, 8]. Stężenie cholesterolu LDL w surowicy krwi, utrzymujące się na wysokim poziomie, nasila procesy zapalne w blaszce miażdżycowej, natomiast obniżenie poziomu cholesterolu we wczesnych fazach zmian może powodować ich zahamowanie, a nawet cofanie się [9]. W redukcji poziomu cholesterolu w blaszkach miażdżycowych znaczącą rolę odgrywają lipoproteiny frakcji HDL (high density lipoprotein) [10]. Dane pochodzące z literatury dowodzą, że niskie stężenie cholesterolu frakcji HDL w surowicy krwi jest istotnym czynnikiem ryzyka wystąpienia ChNS [11].

Celem pracy była ocena wiedzy studentów farmacji Śląskiego Uniwersytetu Medycznego w Katowicach (SUM) na temat czynników ryzyka ChUK. W badanej grupie analizowane były również częstości występowania głównych czynników ryzyka oraz podstawowe działania prewencyjne w kierunku ChUK.

\section{MATERIAŁY I METODY}

Do badań metodą sondażu diagnostycznego wykorzystano autorski kwestionariusz ankiety, który wypełniło 156 studentów (123 kobiety i 33 mężczyzn) III i IV roku kierunku farmacja SUM. Badanie zostało zaopiniowane przez Komisję Bioetyczną SUM nr KNW/0022/KB/173/17. Udział w ankiecie był dobrowolny i anonimowy. Każdorazowo student wypełniał ankietę w obecności ankietera. Nie stosowano limitu czasowego, nie dopuszczano jednak możliwości korzystania z innych źródeł wiedzy i komunikowania się między respondentami. Ankieta składała się z dwóch części. Pierwsza część, będąca przedmiotem analizy niniejszej pracy, obejmowała pytania dotyczące częstości występowania u ankietowanych studentów czynników ryzyka ChUK oraz podstawowych działań istotnych z punktu widzenia prewencji chorób sercowo-naczyniowych przez nich podejmowanych. Trzy pytania dotyczyły danych demograficznych (wiek, płeć, miejsce zamieszkania), dwa kolejne - występowania ChUK u badanych studentów i w ich rodzinach, natomiast pozostałe - gradacji ważności czynników ryzyka ChUK, znajomości wartości własnego wskaźnika BMI, danych o częstości palenia papierosów i spożywaniu alkoholu oraz informacje o działaniach prewencyjnych w zakresie aktywności fizycznej i stosowania zasad zdrowego żywienia. Druga część ankiety obejmowała pytania dotyczące znajomości norm parametrów biochemicznych istotnych w rozwoju zmian w układzie krążenia oraz wiedzy studentów na temat możliwości prowadzenia doradztwa zawodowego w tym kierunku. Wszystkie kwestionariusze zostały wypełnione prawidłowo.

Uzyskane wyniki analizowano statystycznie z wykorzystaniem programu Statistica 12,0 (StatSoft Inc.). Walidację kwestionariusza przeprowadzono, wykorzystując korelację $r$ Spearmana i test $\chi^{2}$ [12]. Zmienne ilościowe przedstawiono jako wartości średnie ( \pm odchylenie standardowe), natomiast jakościowe - jako procentowy udział w analizowanej grupie. W pracy dokonano analizy porównawczej podgrupy kobiet z podgrupą mężczyzn przy użyciu testu $\chi^{2}$ z poprawką Yatesa. Za istotne statystycznie przyjęto różnice, dla których $\mathrm{p}<0,05$.

\section{WYNIKI}

Do analizy włączono 209 ankiet. Zmienność wewnątrzosobniczą, polegającą na sprawdzeniu powtarzalności uzyskanych odpowiedzi dla tych samych 53 studentów w dwóch badaniach ankietowych (w odstępie czasu 7 dni), określono metodą współczynników korelacji Spearmana. Zmienność międzyosobniczą, polegającą na porównaniu średnich częstotliwości badanych cech dla grupy, sprawdzono testem $\chi^{2}$ $(p \leq 0,05)$. Otrzymane wartości $\chi^{2}=10,369(p=0,974)$ oraz średni współczynnik korelacji Spearmana $r=0,979$ wskazują na niską zmienność wewnątrzosobniczą i międzyosobniczą 
oraz wysoką powtarzalność otrzymanych odpowiedzi. Opracowany autorski kwestionariusz może być zatem wykorzystany jako narzędzie badawcze.

\section{Ogólna charakterystyka badanej grupy}

W tabeli 1 przedstawiono ogólną charakterystykę badanej grupy z uwzględnieniem wieku, miejsca zamieszkania, występowania chorób układu krążenia w rodzinie i wskaźnika masy ciała.

W ankietowanej grupie studentów przeważały kobiety $(79 \%$ vs $21 \%$ mężczyzn). Średni wiek badanych wynosił 23,4 $\pm 1,5$ lata. Wykazano znamienną różnicę $\mathrm{w}$ wieku kobiet - 23,2 $\pm 1,4$ lata i ankietowanych mężczyzn - 23,9 $\pm 1,7$ lata.

W całej grupie badanej najwięcej osób (32\%) zamieszkuje miejscowości powyżej 100 tys. mieszkańców, podobnie w podgrupie mężczyzn (42\%). W podgrupie kobiet największy odsetek ankietowanych mieszka na wsi (31\%).
Spośród badanych respondentów 5\% cierpi na choroby układu krążenia (4\% kobiet i 9\% mężczyzn), natomiast u 81\% z nich ChUK występują w rodzinie. Swojego wskaźnika masy ciała nie zna 10\% badanych. W grupie osób, które wiedzą, ile wynosi wartość ich BMI, 77\% zadeklarowało BMI w granicach 18,5-24,9, poniżej 18,5 - 19 osób, powyżej 30 - 1 osoba. Zaobserwowano znamienne statystycznie różnice w liczbie kobiet i mężczyzn z BMI poniżej 18,5 (15\% kobiet vs 0\% mężczyzn) i w grupie z BMI znamionującym nadwagę ( $15 \%$ mężczyzn vs $2 \%$ kobiet).

W tabeli 2 przedstawiono wyniki dotyczące znajomości czynników ryzyka chorób układu krążenia w badanej grupie studentów.

Do najważniejszych czynników ryzyka ChUK wg wskazanych przez studentów należą: nadwaga/otyłość (90\%), nadciśnienie tętnicze (87\%), stres (75\%) oraz mała aktywność fizyczna (70\%). Czynnikami ryzyka ChUK, które były

TABELA 1. Ogólna charakterystyka badanej grupy studentów

\begin{tabular}{|c|c|c|c|c|}
\hline Parametry & $\begin{array}{l}\text { Cała grupa } \\
n=156\end{array}$ & $\begin{array}{l}\text { Kobiety } \\
n=123\end{array}$ & $\begin{array}{c}\text { Mężczyźni } \\
n=33\end{array}$ & $x^{2} ; p$ \\
\hline Wiek (lata), średnia \pm SD & $23,4 \pm 1,5$ & $23,2 \pm 1,4$ & $23,9 \pm 1,7$ & $p=0,03^{*}$ \\
\hline \multicolumn{5}{|l|}{ Miejsce zamieszkania, n (\%) } \\
\hline wieś & $43(28)$ & $38(31)$ & $5(15)$ & 2,$56 ; 0,08$ \\
\hline miejscowość do 14999 & $16(10)$ & $10(8)$ & $6(18)$ & 1,$82 ; 0,11$ \\
\hline miasto 15 000-49999 & $27(17)$ & $21(17)$ & $6(18)$ & 0,$02 ; 1,00$ \\
\hline miasto >100 000 & $49(32)$ & $35(28)$ & $14(42)$ & 1,$68 ; 0,14$ \\
\hline ChUK w wywiadzie, n (\%) & $8(5)$ & $5(4)$ & $3(9)$ & 0,$52 ; 0,37$ \\
\hline ChUK w rodzinie, n (\%) & $126(81)$ & $99(80)$ & $27(82)$ & 0,$01 ; 1,00$ \\
\hline \multicolumn{5}{|l|}{ Wskaźnik masy ciała, n (\%) } \\
\hline poniżej 18,5 & $19(13)$ & $19(15)$ & 0 & 3,$73 ; 0,02 *$ \\
\hline $18,5-24,9$ & $111(77)$ & $92(75)$ & $19(58)$ & 0,$44 ; 0,44$ \\
\hline powyżej 30 & $1(0,7)$ & 0 & $1(3)$ & 0,$65 ; 0,19$ \\
\hline
\end{tabular}

n - liczebność; SD - odchylenie standardowe; ChUK - choroby układu krążenia

* różnice między kobietami i mężczyznami znamienne statystycznie przy p < 0,05

TABELA 2. Znajomość czynników ryzyka chorób układu krążenia (ChUK)

\begin{tabular}{|c|c|c|c|c|}
\hline Czynniki ryzyka ChUK & $\begin{array}{c}\text { Cała grupa } \\
n=156\end{array}$ & $\begin{array}{l}\text { Kobiety } \\
n=123\end{array}$ & $\begin{array}{c}\text { Mężczyźni } \\
n=33\end{array}$ & $x^{2} ; p$ \\
\hline Dyslipidemia, n (\%) & $45(29)$ & $39(32)$ & $6(18)$ & 1,$71 ; 0,19$ \\
\hline Palenie tytoniu, n (\%) & $102(65)$ & $85(69)$ & $17(52)$ & 2,$82 ; 0,07$ \\
\hline Nadwaga/otyłość, n (\%) & $141(90)$ & $115(93)$ & $26(78)$ & 4,$89 ; 0,02^{*}$ \\
\hline Cukrzyca, n (\%) & $73(47)$ & $62(50)$ & $11(33)$ & 2,$40 ; 0,11$ \\
\hline Nadciśnienie tętnicze, n (\%) & $136(87)$ & $107(87)$ & $29(88)$ & 0,$03 ; 1,00$ \\
\hline Czynniki genetyczne, n (\%) & $72(46)$ & $55(45)$ & $17(52)$ & 0,$25 ; 0,56$ \\
\hline Mała aktywność fizyczna, n (\%) & $110(70)$ & $88(72)$ & $22(67)$ & 0,$11 ; 0,67$ \\
\hline Wiek, n (\%) & $40(26)$ & $29(24)$ & $11(33)$ & 0,$84 ; 0,27$ \\
\hline Płeć, n (\%) & $12(8)$ & $8(7)$ & $4(12)$ & 0,$50 ; 0,28$ \\
\hline Stres, n (\%) & $117(75)$ & $90(73)$ & $27(82)$ & 0,$63 ; 0,37$ \\
\hline Nieodpowiednia dieta, n (\%) & $106(68)$ & $82(67)$ & $24(73)$ & 0,$21 ; 0,67$ \\
\hline Spożywanie alkoholu, n (\%) & $66(42)$ & $56(46)$ & $10(30)$ & 1,$89 ; 0,16$ \\
\hline
\end{tabular}

n - liczebność

* różnice między kobietami i mężczyznami znamienne statystycznie przy p <0,05 
TABELA 3. Występowanie czynników ryzyka chorób układu krążenia w ankietowanej grupie

\begin{tabular}{|c|c|c|c|c|}
\hline Parametry & $\begin{array}{c}\text { Cała grupa } \\
n=156\end{array}$ & $\begin{array}{c}\text { Kobiety } \\
n=123\end{array}$ & $\begin{array}{c}\text { Mężczyźni } \\
n=33\end{array}$ & $x^{2} ; p$ \\
\hline Nieodpowiednia dieta, n (\%) & $59(38)$ & $40(33)$ & $19(58)$ & 5,$60 ; 0,01^{*}$ \\
\hline Bierne palenie, n (\%) & $64(45)$ & $50(41)$ & $14(42)$ & 0,$55 ; 0,37$ \\
\hline $\begin{array}{l}\text { Aktywność fizyczna, n (\%) } \\
\text { duża } \\
\text { średnia } \\
\text { niska } \\
\text { żadna }\end{array}$ & $\begin{array}{c}12(8) \\
89(57) \\
47(30) \\
8(5)\end{array}$ & $\begin{array}{c}9(7) \\
71(58) \\
35(28) \\
8(7)\end{array}$ & $\begin{array}{c}3(9) \\
18(54) \\
12(36) \\
0\end{array}$ & $\begin{array}{c}0,001 ; 0,72 \\
0,02 ; 0,84 \\
0,44 ; 0,39 \\
1,12 ; 0,20\end{array}$ \\
\hline Spożywanie alkoholu, n (\%) & $102(66)$ & $78(63)$ & $24(73)$ & 0,$54 ; 0,41$ \\
\hline
\end{tabular}

n - liczebność

* różnice między kobietami i mężczyznami znamienne statystycznie przy $p<0,05$

najrzadziej wskazywane, są: płeć (8\%), wiek (26\%) oraz dyslipidemię (29\%). Porównując podgrupy kobiet i mężczyzn, stwierdzono znamienną statystycznie różnicę w odniesieniu do nadwagi/otyłości - 93\% kobiet wskazało nadwagę jako czynnik ryzyka ChUK vs 78\% mężczyzn.

W niniejszej pracy przeanalizowano również występowanie czynników ryzyka w grupie badanych studentów (tab. 3).

Prawie wszyscy ankietowani wskazali, że znają zasady zdrowego żywienia, jednak niewielu - ponad $60 \%$ z nich je stosuje, w tym znacząco więcej kobiet niż mężczyzn (67\% vs 42\%). Najczęściej występującym czynnikiem ryzyka ChUK w badanej grupie jest palenie papierosów, które dotyczy 15\% respondentów ( $27 \%$ mężczyzn vs $11 \%$ kobiet, $\mathrm{p}=0,03)$. Na bierne palenie narażonych jest natomiast $45 \%$ ankietowanych. Z kolei, $57 \%$ studentów przyznało, że poziom ich aktywności fizycznej jest średni, natomiast $5 \%$ z nich nie ćwiczy wcale. Spożywanie alkoholu zadeklarowało $66 \%$ ankietowanych, przy czym nie wykazano różnic w podgrupach kobiet i mężczyzn.

\section{DYSKUSJA}

Choroby układu krążenia należą do istotnych problemów zdrowotnych XXI w. Zarówno w Polsce, jak i na świecie ciągle stanowią główną przyczynę śmiertelności [13]. Analiza zgonów spowodowanych chorobami sercowo-naczyniowymi (m.in. chorobą niedokrwienną serca czy chorobą naczyń mózgowych) wykazała, że jest ona 2-krotnie wyższa w krajach, które do Unii Europejskiej (UE) wstąpiły w 2004 r., w porównaniu z wcześniejszymi członkami UE, co wydaje się być wynikiem wyższego poziomu rozwoju krajów zachodnich (większe wydatki na zdrowie, łatwiejszy dostęp pacjentów kardiologicznych do opieki medycznej oraz lepsza farmakologiczna kontrola nadciśnienia i hipercholesterolemii) [13].

Badania NATPOL 2011 przeprowadzone na dużej grupie dorosłych Polaków wskazały, że ponad 60\% cierpi na hipercholesterolemię, przy czym poziom cholesterolu całkowitego i cholesterolu frakcji LDL jest szczególnie wysoki w grupie wiekowej 40-59 lat [14]. W grupie ankietowanej w niniejszej pracy jedynie niecałe $30 \%$ studentów wskazało dyslipidemię jako czynnik ryzyka ChUK.
W badanej grupie $60 \%$ ankietowanych jest narażonych na dym tytoniowy pochodzący bezpośrednio z wypalanego w sposób czynny papierosa lub wdychanego ze strumienia bocznego poprzez przebywanie wśród palących. Do czynnego palenia papierosów przyznało się 15\% studentów, znacznie częściej byli to mężczyźni. Wyniki zbliżone do danych obserwowanych w niniejszej pracy uzyskali Kawalec i wsp. [15] w grupie kobiet pracujących umysłowo. Palenie papierosów jest jednym z najsilniejszych czynników ryzyka wystąpienia miażdżycy i ChNS, zwłaszcza jeśli współtowarzyszą mu genetyczne czynniki zwiększające ryzyko wystąpienia chorób sercowo-naczyniowych $[16,17]$. Prawie połowa ankietowanych, zarówno palących, jak i nigdy niepalących, jest również narażona na bierne palenie. Wcześniejsze badania wskazują, że bierne palenie zwiększa ryzyko zwapnienia tętnicy wieńcowej u osób niepalących $[18,19]$. Yankelevitz i wsp. wykazali również, że im większe jest narażenie na bierne palenie, tym odsetek głównych naczyń, w których tworzą się blaszki miażdżycowe lub zwężenia, wzrasta [20].

Wyniki ankiety wskazują, że badani studenci uznają nadwagę/otyłość za jeden z najważniejszych czynników ryzyka ChUK; znamiennie częściej kobiety niż mężczyźni. Wskaźnikiem BMI w granicach normy charakteryzuje się prawie $80 \%$ ankietowanych. Z kolei, prawie 6\% respondentów dotyczy problem nadwagi/otyłości, zdecydowanie częstszy u mężczyzn niż u kobiet. Jest to o tyle zaskakujące, że prawie wszyscy ankietowani zadeklarowali znajomość zasad zdrowego żywienia i znamiennie częściej stosują je właśnie mężczyźni. Wyjaśnieniem może być jednak fakt, że aż 38\% z badanych studentów nie prowadzi zdrowej diety. Dieta bogata w nasycone kwasy tłuszczowe, cholesterol i sól przyśpiesza rozwój miażdżycy, natomiast diety roślinne - obniżają to ryzyko [21]. Zatem złe odżywianie może w przyszłości przyczyniać się do wzrostu odsetka osób z nadwagą/otyłością, a to z kolei wiąże się z narażeniem na rozwój ChUK. Zaobserwowana w badaniach własnych częstość nadwagi jest porównywalna z wynikami, które otrzymali Lenart i wsp. Odsetek osób z nadwagą wynosił odpowiednio 4\% i 10\% w grupach studentów medycyny I i VI roku [22]. W pracy tej, podobnie do niniejszej, nadwaga/otyłość również występuje częściej wśród mężczyzn niż u kobiet w badanej grupie studentów. Z kolei w grupie 
studentów pielęgniarstwa Uniwersytetu Medycznego im. Piastów Śląskich we Wrocławiu nadwaga występowała u znacząco większej liczby ankietowanych (prawie 33\%) w porównaniu z badaniami własnymi [23].

Pozytywną odpowiedź na pytanie dotyczące rodzinnej historii ChUK dało 81\% osób. W badaniu przeprowadzonym przez Kołtuniuk i Rosińczuk [23] ponad 75\% studentów również potwierdziło rodzinną historię ChUK. Czynniki genetyczne w procesie miażdżycy mają znaczący wpływ na to, w jakim wieku ujawni się choroba, a także na stopień zaawansowania zmian klinicznych oraz odpowiedź na stosowaną terapię. Niewątpliwie genetyczne predyspozycje są głównym czynnikiem ryzyka w przypadku zawału serca dotykającego pacjentów w młodym wieku lub przedwczesnej choroby niedokrwiennej serca [24]. Rodzinna historia ChNS z markerami miażdżycy tętnic (grubość kompleksu śródbłonek-błona środkowa w tętnicy szyjnej czy markery stanu zapalnego - CRP, fibrynogen i D-dimery) jest czynnikiem predysponującym do wystąpienia choroby, również przy współistnieniu tradycyjnych czynników ryzyka [25].

Wszyscy ankietowani studenci płci męskiej wskazali, że w mniejszym lub większym stopniu są aktywni fizycznie. Natomiast aż 7\% kobiet wskazało, że nie ćwiczy w ogóle. Z kolei w badaniach Rząca i wsp. [26] aż 70\% ankietowanych obciążonych ryzykiem ChUK spędza czas wolny biernie. Tymczasem regularny wysiłek fizyczny korzystnie modyfikuje wiele z czynników przyspieszających rozwój miażdżycy. Obserwowany jest pozytywny wpływ aktywności fizycznej na poziom lipidów (wzrost stężenia cholesterolu frakcji HDL, natomiast redukcja cholesterolu frakcji LDL), normalizację ciśnienia tętniczego krwi, poprawę tolerancji glukozy czy wzrost wrażliwości tkanek na insulinę. Ponadto zmniejsza się stężenie czynników krzepnięcia takich jak fibrynogen oraz czynnik VII. Aktywność fizyczna sprzyja również utrzymaniu prawidłowej wagi ciała i kondycji psychofizycznej, co pośrednio także może wpływać na zmniejszenie ryzyka ChNS.

Promowanie zdrowego trybu życia przez stosowanie zdrowej, zbilansowanej diety, zaprzestanie palenia, regularne ćwiczenia fizyczne, jak również działania mające na celu zapobieganie wystąpieniu nadciśnienia tętniczego czy cukrzycy typu II, są elementami profilaktyki pierwotnej chorób układu krążenia [27]. Świadomość czynników ryzyka chorób sercowo-naczyniowych i ich wczesne rozpoznanie pozwala na ograniczenie ich negatywnego wpływu na zdrowie człowieka. Wyniki niniejszej ankiety wskazują jednak, że ciągłe kształcenie w zakresie profilaktyki pierwotnej chorób układu krążenia powinno dotyczyć każdego, również osób, które są lub będą związane zawodowo z medycyną.

\section{WNIOSKI}

1. W ankietowanej grupie najczęściej występującym czynnikiem ryzyka ChUK jest palenie papierosów (czynne lub bierne).

2. Co trzeci ankietowany student, mimo znajomości zasad zdrowego żywienia, nie stosuje ich oraz wykazuje niski poziom aktywności fizycznej lub całkowity jej brak.

\section{PIŚMIENNICTWO}

1. Saltiki K, Doukas C, Kanakakis J, Anastasiou E, Mantzou E, Alevizaki M. Severity of cardiovascular disease in women: relation with exposure to endogenous estrogen Maturitas 2006;55(1):51-7.

2. Frohlich M, Sund M, Lowel H, Imhof A, Hoffmeister A, Koenig W. Independent association of various smoking characteristics with markers of systemic inflammation in men. Results from a representative sample of the general population (MONICA Augsburg Survey 1994/95). Eur Heart J 2003;24(14):1365-72.

3. Leone A. Relationship between cigarette smoking and other coronary risk factors in atherosclerosis: risk of cardiovascular disease and preventive measures. Curr Pharm Des 2003;9(29):2417-23.

4. Visscher TL, Seidell JC. The public health impact of obesity. Annu Rev Public Health 2001;22:355-75.

5. Kenchaiah S, Evans JC, Levy D, Wilson PW, Benjamin EJ, Larson MG, et al. Obesity and the risk of heart failure. N Engl J Med 2002;347(5):305-13.

6. Peeters A, Barendregt JJ, Willekens F, Mackenbach JP, Al Mamun A, Bonneux $\mathrm{L}$, et al. Obesity in adulthood and its consequences for life expectancy: a life-table analysis. Ann Intern Med 2003;138(1):24-32.

7. Stamler J, Daviglus ML, Garside DB, Dyer AR, Greenland P, Neaton JD. Relationship of baseline serum cholesterol levels in 3 large cohorts of younger men to long-term coronary, cardiovascular, and all-cause mortality and to longevity. JAMA 2000;284(3):311-8.

8. Vasankari T, Ahotupa M, Toikka J, Mikkola J, Irjala K, Pasanen P, et al. Oxidized LDL and thickness of carotid intima-media are associated with coronary atherosclerosis in middle-aged men: lower levels of oxidized LDL with statin therapy. Atherosclerosis 2001;155(2):403-12.

9. Maron DJ, Fazio S, Linton MF. Current perspectives on statins. Circulation 2000;101(2):207-13.

10. Cho BH, Park JR, Nakamura MT, Odintsov BM, Wallig MA, Chung BH. Synthetic dimyristoylphosphatidylcholine liposomes assimilating into highdensity lipoprotein promote regression of atherosclerotic lesions in cholesterol-fed rabbits. Exp Biol Med (Maywood) 2010;235(10):1194-203.

11. Sacks FM; Expert Group on HDL Cholesterol. The role of high-density lipoprotein (HDL) cholesterol in the prevention and treatment of coronary heart disease: expert group recommendations. Am J Cardiol 2002;90(2):139-43.

12. Wyka J. Stan odżywienia ludzi po 60. roku życia w aspekcie uwarunkowań żywieniowych, zdrowotnych, środowiskowych i socjodemograficznych. Wrocław: Wydawnictwo Uniwersytetu Przyrodniczego we Wrocławiu; 2009. p. 50-8

13. Helis E, Augustincic L, Steiner S, Chen L, Turton P, Fodor JG. Time trends in cardiovascular and all-cause mortality in the 'old' and 'new' European Union countries. Eur J Cardiovasc Prev Rehabil 2011;18(3): 347-59.

14. Zdrojewski T, Solnica B, Cybulska B, Bandosz P, Rutkowski M, Stokwiszewski J, et al. Prevalence of lipid abnormalities in Poland. The NATPOL 2011 survey. Kardiol Pol 2016;74(3):213-23.

15. Kawalec E, Gabryś T, Brzostek T, Reczek A, Malinowska-Lipień I, Cichoń B. Czynniki ryzyka choroby niedokrwiennej serca u kobiet pracujących umysłowo. Probl Pielęg 2008;16(4):325-30.

16. Sarecka B, Zak I, Krauze J. Synergistic effects of the polymorphisms in the PAI-1 and IL- 6 genes with smoking in determining their associated risk with coronary artery disease. Clin Biochem 2008;41(7-8):467-73.

17. Zak I, Sarecka-Hujar B, Krauze J. Cigarette smoking, carrier state of A or G allele of $46 \mathrm{~A}>\mathrm{G}$ and $79 \mathrm{C}>\mathrm{G}$ polymorphisms of beta2-adrenergic receptor gene, and the risk of coronary artery disease. Kardiol Pol 2008;66(4):380-6.

18. Yankelevitz DF, Henschke CI, Yip R, Boffetta P, Shemesh J, Cham MD, et al. Second-hand tobacco smoke in never smokers is a significant risk factor for coronary artery calcification. JACC Cardiovasc Imaging 2013;6(6):651-7.

19. Peinemann F, Moebus S, Dragano N, Möhlenkamp S, Lehmann N, Zeeb H, et al. Secondhand smoke exposure and coronary artery calcification among nonsmoking participants of a population-based cohort. Environ Health Perspect 2011;119(11):1556-61.

20. Yankelevitz DF, Cham MD, Hecht H, Yip R, Shemesh J, Narula J, et al. The association of secondhand tobacco smoke and CT angiography-verified coronary atherosclerosis. JACC Cardiovasc Imaging 2017;10(6):652-9.

21. Parol D, Mamcarz A. Diety roślinne w kontekście chorób układu sercowonaczyniowego. Folia Cardiol 2015;10(2):92-9. 
22. Lenart A, Mosio J, Knap K, Dziad D, Adamik K, Olszowska M. Wpływ znajomości czynników ryzyka sercowo-naczyniowego na styl życia studentów I i VI roku kierunku lekarskiego. Przegl Lek 2014;71(7):389-93.

23. Kołtuniuk A, Rosińczuk J. Występowanie czynników ryzyka chorób układu krążenia wśród studentów pielęgniarstwa - doniesienie wstępne. Hygeia Public Health 2015;50(1):210-4.

24. Nasir K, Budoff MJ, Wong ND, Scheuner M, Herrington D, Arnett DK, et al. Family history of premature coronary heart disease and coronary artery calcification: Multi-Ethnic Study of Atherosclerosis (MESA). Circulation 2007;116(6):619-26.
25. Pandey AK, Pandey S, Blaha MJ, Agatston A, Feldman T, Ozner M, et al. Family history of coronary heart disease and markers of subclinical cardiovascular disease: where do we stand? Atherosclerosis 2013;228(2): 285-94.

26. Rząca M, Charzyńska-Gula M, Stanisławek A. Świadomość zagrożenia chorobą niedokrwienną serca u osób z grup ryzyka a zachowania zdrowotne. Probl Pielęg 2011;19(3):348-52.

27. Tomasik T. Prewencja chorób układu krążenia w podstawowej opiece zdrowotnej. Zdrow Publ Zarz 2014;12(4):338-51. 